\title{
MANAJEMEN SUMBER DAYA MANUSIA
}

\author{
Sakban ${ }^{1}$, Ifnaldi Nurmal ${ }^{2}$, Rifanto bin Ridwan ${ }^{3}$ \\ Program Pascasarjana IAIN Curup ${ }^{1,2,3}$ \\ syakban2019@gmail.com ${ }^{1}$
}

\begin{abstract}
ABSTRAK
Tujuan penelitian ini untuk mengetahui manajemen sumber daya manusia di Madrasah Aliyah Al-Mathitiriyah Kecamatan Rupit. Jenis penelitian ini adalah penelitian Kualitatif dengan metode desktriptif analisis yaitu metode yang berusaha memaparkan secara sistematis materi-materi pembahasan yang berasal dari berbagai sumber untuk kemudian dianalisis guna memperoleh hasil sebagai kesimpulan. Hasil Penelitian, kepala sekolah sangat berperan sekali dalam meningkatkan dan motivasi para guru, staf /karyawan, dalam meningkatkan prestasi siswa/I nya, yang sudah berjalan secara efektif dan kondisonal. Dalam memberikan peluang dan kesempatan kepada para gurunya untuk mengikuti pendidikan dan pelatihan yang diadakan oleh pemerintah dan memberikan kesempatan bagi para guru yang untuk melanjutkan jenjang studi yang lebih tinggi, Simpulan, kepala MA Al-Mathiriyah melaksanakan, merencanakan, dan professional, serta ahli bidangnya, serta mampu memberi penghargaan, serta memberikan hukuman, jika melanggar kode etik guru.
\end{abstract}

Kata Kunci: Manajemen Sumber Daya Manusia, Kinerja

\begin{abstract}
The purpose of this study was to determine human resource management in the Madrasah Aliyah Al-Mathitiriyah Rupit District. This type of research is qualitative research with descriptive analytical methods, namely methods that attempt to systematically explain the discussion material originating from various sources for later analysis in order to obtain results as a conclusion. Research Results, principals are very instrumental in increasing and motivating teachers, staff / employees, in improving student achievement, which has been effective and conditional. In providing opportunities and opportunities for the teachers to take part in education and training held by the government and provide opportunities for teachers to continue their higher level of study, Conclusion, the head of MA Al-Mathiriyah carries out, plans, and professionals, as well as field experts, and able to give awards, and provide penalties, if it violates the teacher's code of ethics.
\end{abstract}

Keywords: Human Resource Management, Performance

\section{PENDAHULUAN}

Sumber daya yang berkualitas antara lain ditunjukkan oleh kinerja dan produktivitas yang tinggi. Kinerja seseorang berkaitan dengan kualitas prilaku yang berorientitas pada tugas dan pekerjaan. Demikian halnya dengan kinerja guru yang mana kinerja guru ini dapat dilihat dari dua sudut administrasi dan 
pengembangan profesi. Kinerja merupakan perwujudan kerja yang dilakukan oleh karyawan atau organisasi, sehingga perlu diupayakan untuk meningkat kinerja factor-faktor yang mempengaruhi kompensasi ini doantaranya ialah kinerja. Kualitas kinerja, dan motivasi kerja.

Dalam meningkatkan mutu pendidikan maka setiap Organisasi harus membutuhkan seorang pemimpin yang bisa membawa personil lebih baik, terutama di lembaga pendidkan, kepala madrasah sangat berperan penting terhadap guru, Karena Kepala Madrasah yang membawa perubahan yang lebih baik, kemudian guru merupakan komponen utama dalam proses belajar mengajar, yang ikut berperan dalam usaha pembentukan sumber daya manusia dalam bidang pembangunan. Sebagaimana sucipto dan Raflis Kokasih menyatakan bahwa guru sebagai pendidikan propesonal mempunyai citra yang baik di masyarakat apabila dapat menunjukkan kepada masyarakat bahwa ia layak menjadi panutan atau teladan masyarakat sekelilingnya (Soecipto, 2007). Masyarakat akan melihat bagaimana sikap dan perbuatan guru itu sehari-hari, apakah memang ada yang patut di teladani atau tidak. Bagaimanan guru meningkatkan pelayanannya, meningkatkan pengetahuannya, memberi arahan dan kepada anak didiknya, dan bagaimanan cara guru berpakaian, berbicara serta gaya bergaul baik dengan siswa atau teman-temannya serta anggota masyarakat, sering menjadi perhatian masyarakat luas.

Adapun di samping kerja guru yang baik, Guru juga harus memiliki disiplin yang baik juga dalam bekerja, yang dimaksud disini sejalan dengan pendapat yang dikemukakan adalah pemantauan secara sadar akan aturan-aturan yang telah ditentukan: yaitu pemantauan aturan yang dilakukan oleh guru dalam menjalankan tugas dan fungsinya sebagai pengajar, pendidik dan pembimbing terhadap keberhasilan siswa dalam proses belajar mengajar di sekolah (Sahertian, 1990). Dalam proses pembelajaran siswa, setiap guru mempunyai keinginan agar semua siswanya dapat memperoleh hasil belajar yang baik dan memuaskan. Harapan tersebut sering kali kandas tidak terwujud, sering mengalami kesulitan dalam belajar. Guru merupakan personil sekolah yang memiliki kesempatan untuk bertatap muka lebih banyak dengan siswa dibandingkan dengan personil sekolah laiinya. Oleh sebab itu, pesan dan tanggung jawab guru dalam pelaksanaan bimbingan dan konseling disekolah sangat diharapkan.

Dilihat dari sisi aktualisasinya, pendidikan merupakan proses interaksi anatara guru dengan siswa untuk mencapai tujuan pendidikan yang ditentukan. Pendidikan, peserta didik, dan tujuan pendidikan merupakan komponen utama pendidikan. Ketiganya membentuk suatu triagle, yang jika hilang salah satuya, maka hilanglah hakikat pendidikan. Namun demikian dalam situasi tertentu tugas guru dapat diwakilkan atau dibantu oleh unsur lain seperti media teknologi, tetapi tidak dapat digantikan. Medidik adalah pekerjaan professional. Oleh karena itu guru sebagai pelaku utama pendidikan merupakan pendidkan professional. 
MA Al-Mathiriyah Muara Rupit masalah kemajuan pendidikan ini sudah boleh dikatakan cukup baik. Hal ini dapat dilihat dengan tersedianya sarana perasarana pendidikan yang ada di MA Al-Mathiriyah Muara Rupit tersebut adalah salah satu lembaga pendidikan agama tingkat MA yang ada di Muara Rupit.MA Al-Mathiriyah Muara Rupit ini adalah bukan merupakan pendidikan umum, melainkan hanyalah lembaga pendidikan non formal agama. Dengan demikian lembaga pendidikan tersebut hanya sekedar mempelajari bidang Study Agama saja sebagaimana kurikulum yang berlaku pada MA Al-Mathiriyah Muara Rupit.

Disamping hal tersebut, rasanya perlu penulis kemukakan bahwa MA AlMathiriyah Muara Rupit ini adalah lembaga pendidikan swasta yang mayoritas tenaga pengajarannya adalah terdiri dari pada guru swasta. Hal ini barang kali yang menyebabkan kurang faktor kedisiplinan guru yang mengajar pada madrasah tersebut dimana tenaga pengajarnya mayoritas adalah berstatus swasta/honorer, yang sudah barang tentu juga membawa pengaruh dalam proses belajar mengajar pada sekolah tersebut.

Mengingat mayoritas tenaga pengajar atau guru madrasah adalah swasta atau honor, jumlah seluruh guru yang ada di MA Al-Mathiriyah Muara Rupit adalah 15 orang dan mereka juga mempunyai tanggung jawab di luar sekolah dalam rangka untuk memenuhi kebutuhan primernya dalam aktivitas hidup dan kehidupannya sehari-hari, maka hal ini sering menyebabkan guru-guru tersebut absen dalam pelaksanaan tugasnya mengajar, yang pada akhirnya mengakibatkan kurangnya kedisiplinan guru dalam kegiatan, yang sudah barang tentu berakibat pula terhadap kurangnya kelancaran dalam proses belajar mengajar.Dilihat dari peserta didik yang belajar di MA Al-Mathiriyah Muara Rupit ini, jumlah Siswa kelas satu sampai kelas 3 adalah 120 orang dan mayoritas adalah siswa-siswi MA Al-Mathiriyah Muara Rupit dalam lingkup pesantren.

Dari uraian di atas, maka jelaslah bahwa pemberian contoh suri tauladan yang baik akan sangat berpengaruh terhadap anak didik, terlebih-lebih disiplinya kerja guru sebagai pendidik akan sangat berpengaruh pula terhadap disiplinnya siswa dalam memberikan motivasi belajar siswa dalam rangka menunjang keberhasilan dalam suatu proses pendidikan adalah kedisiplinan dan tenaga pendidik itu sendiri dalam melaksanakan tugas-tugasnya, sebagaimana di ketahui apa adanya kedisiplinan maka proses belajar mengajar dalam mencapai tujuan pendidikan tidaka akan berhasil sepenuhnya.

Proses pembinaan bagi terwujudnya pribadi yang disiplin memang bukanlah pekerjaan yang ringan, apalagi ketika pembinaan itu ditunjukkan kepada banyak orang. Sehingga sangat dibutuhkan ketelatenan yang tinggi dalam membina mereka agar mereka terbentuk menjadi manusia-manusia yang disiplin, maka sudah tidak asing lagi bahwa begitu banyak lembaga pendidikan yang masih belum begitu berhasil dalam membina disiplin guru. Kondisi inilah yang tengah 
terjadi di MA Al-Mathiriyah Muara Rupit sehingga hasil yang di dapatkan belum terwujud sebagaimana yang diharapkan.

Mengingat MA Al-Mathiriyah Muara Rupit ini merupakan madrasah yang baru berkembang sehingga fasilitas untuk memperlancar proses belajar mengajar belum begitu memadai dan belum dapat dimanfaatkan secara maksimal.Adapun faktor-faktor penerapan kinerja guru ini erat kaitannya dengan masalah prestasi belajar siswa. Kinerja guru salah satu faktor yang mempengaruhi prestasi belajar siswa. Sesuai dengan dengan ovservasi penulis pada MA Al-Mathiriyah Muara Rupit, penulis menemukan suatu kenyataan bahwa terdapat guru yang terlambat masuk mengajar dikelas untuk mengajar sementara murid masih ada juga yang kekeliaran dikelas. Ada sebagian murid yang ribut, asyik dengan bicara dengan temannya, murid yang berpakaian tidak seragam, ada yang pakai sandal dan bahkan ada juga penulis temukan guru-guru yang mengajar juga pakai sandal, serta kurang memadai sarana prasarana yang ada (Dharma, 2005).

\section{METODE PENELITIAN}

Jenis penelitian ini adalah penelitian Kualitatif dengan metode desktriptif analisis yaitu metode yang berusaha memaparkan secara sistematis materi-materi pembahasan yang berasal dari berbagai sumber untuk kemudian dianalisis guna memperoleh hasil sebagai kesimpulan. Penelitian kualitatif berarti prosese ekspolrasi dan memahami makna prilaku individu ataupun kelompok. Menggambarkan masalah social atau masalah kemanusiaan.Penelitian ini berupaya untuk mengetahui dan menelaah tentang " menajemen Sumber daya manusia dalam meningkatkan kerja guru di Madrasah Aliyah Al-Mathitiriyah Kecamatan Rupit”.

Penelitian ini dilakukan di MAN Al-Mathiriyah Lawang Agung Kecamatan rupit Kabupaten Musi Rawas Utara selama enam bulan, terhitung mulai tanggla 16 Desember 2017 Sampai dengan Juni 2018. Tempat Penelitian Di MAN AlMathiriyah Lawang Agung Kecamatan rupit Kabupaten Musi Rawas Utara. Peneliti tertarik melakukan penelitian di sekolah ini karena sekolah ini di pimpin oleh seorang kepala sekolah wirausahawan. Kepala sekolah MAN Al-Mathiriyah Lawang Agung Kecamatan rupit Kabupaten Musi Rawas Utara adalah seorang kepala sekolah yang kareatif dan inovatif, beliau dapat bimbingan dan melatih para guru staff tat usaha untuk menumbuhkan dan menciptkan sekolah dab santri yang berbasis inovasi, kretivitas yang sedang menjadi Irend utama adalah bagaimana santri dalam menghadapi masa dunia kedepannya dalam arti mempersiapkan sumber dayamanusia dari sekarang melalui pendidikan.

Guru sebagai informasi kunci (key information), sedangkan kepala madrasah dan siswa sebagai informasi tambahan. Pengumpulan data dan informasi dalam penelitian ini penulis mengunakan metode sebagai berikut: 


\section{Metode Observasi}

Dengan menggunakan metode observasi ini peneliti mengamati secara langsung kegiatan yang di jalan Oleh MA Al-Mathiriyah Tersebut yang di bombing dan di latih secara langsung oleh kepala sekolah. Di sini kepala sekolah berperan melatih para guru,staf tata usaha dan peserta didik agar menjadi kaderisasi sekolah dalam menghadapi era globalisasi. Selain itu juga Adapun Ovservasi dalam penelitian ini meliputi: a) historis Dan Geografis Madrasah Aliyah Al-Mathiriyah Kecamatan Rupit. Kabupaten Musi Rawas Utara, b) keadaan Guru Dan Pegawai Madrasah Aliyah Al-Mathiriyah Kecamatan Rupit. Kabupaten Musi Rawas Utara, c) keadaan Siswa Madrasah Aliyah Al-Mathiriyah Kecamatan Rupit. Kabupaten Musi Rawas Utara, d) keadaan Sarana Dan Prasarana Madrasah Aliyah Al-Mathiriyah Kecamatan Rupit. Kabupaten Musi Rawas Utara.

\section{Metode Wawancara (Interview)}

Dalam penelitian ini peneliti mewawancarai kepala sekola sebagai key informan, dilanjutkan mewawancarai guru mata pelajaran sebagai subyek yang menerapkan srategi kepala sekolah dalam meningkatkan kinerja guru di Madrasah Aliyah Al Mathiriah Kec. Rupit. Kabupaten Musi Rawas Utara. Adapun wawancara ini mengenai; a) bentuk peran kepala sekolah dalam meningkatkan kinerja guru yang diterapkan dalam proses belajar mengajar di Madrasah Aliyah Al Mathiriah Kecamatan Rupit. Kabupaten Musi Rawas Utara, b) strategi apa yang digunaka oleh kepala madrsah dalam meningkatkan kinerja guru di Madrasah Al Mathiriah Kecamatan Rupit. Kabupaten Musi Rawas Utara, c) kendalah yang di hadapi kepala madrasah dalam menerapkan kinerja guru terhadap proses belajar mengajar di Madrasah Aliyah Al-Mathiriyah Kecamatan Rupit. Kabupaten Musi Rawas Utara.

\section{Metode Dokumentasi}

Studi dokumen merupakan pelengkap dari penggunaan metode observasi dan wawancara dalam penelitian kualitatif. Data dokumen yang diteliti di sini adalah perpustakaan sekolah, jumlah siswa dan tenaga guru, jumlah sarana dan prasarana, dan struktur organisasi Madrasah Aliyah Al Mathiriah Kec. Rupit. Kabupaten Musi Raws utara yang mendukung dalam penelitian ini. Setelah data terkumpul, maka data tersebut dianalisa secara kuantitatif, yaitu menggunakan secara sebagai berikut.

\section{Analisis Domain}

Dari pengertian diatas dan contoh tersebut didapati petunjuk tentang bagaimana cara mempergunakan analisis domain, cara berpikir ini digunakan untuk memperoleh gambaran umum tentang daerah yang di teliti yaitu Madrasah Aliyah Al Mathiriah Kecamatan Rupit Kabupaten Musi Rawas Utara, maka 
tercakup dalamnya letak geografis, visi dan misi, struktur organisasi, keadaan tenaga pengejar, dan keadaan siswa yang semua ini termasuk unsur domain.

\section{Analisis Taksonomi}

Pada analisis ini fokus penelitian terbatas pada domain tertentu yang sangat dalam upaya mendeskripsikan atau menjelaskan fenomena penelitian. Dalam menggunakan taksonomi penulis lebih mengutamakan penjelasan beberapa masalah, kejadian dan peristiwa yang terjadi di lapangan atau seluruh masalah yang diteliti lebih terfokus kepada beberapa masalah yang di teliti penulis sendiri.

\section{Analisis Komponensial}

Dengan menggunakan komponensial ini penulis mengambil suatu kesimpulan dari data wawancara yang bersifat umum atau domain sehingga terjadi suatu satu kesatuan yang utuh dan sempurna.

\section{HASIL DAN PEMBAHASAN}

\section{Manajemen sumber daya manusia dan tenaga pendidikan dalam meningkatkan pengeloaan kinerja guru}

Dari beberapa hasil wawancara diatas, penulis dapat menarik kesimpulan bahwa, etos kerja dan kinerja guru itu sangat erat kaitannya dengan kinerja guru, sehingga proses kegiatan dan usaha MA Al-Mathiriyah Rupit berjalan sesuai dengan visi dan misi MA Al-Mathiriyah.

Kalau berbicara mengenai masalah kepala medrasah dalam memimpin madrasah terutama di di MA Al-Mathiriyah, agar madrasah-madrasah ini tidak dipandang sebelah mata oleh mayarakat khususnya di kabupaten musi rawas utara, maka perlu adanya usaha- usaha yang harus dilakukan dan bagaimana upaya kepala MA Al-Mathiriyah rupit menjalankan tugasnya, sehingga bisa bersaing dengan sekolah-sekolah lainnya setingkat SLTA khususnya di kabupaten musi rawas utara. Berikut walwancara penulis dengan kepala MA Al-Mathiriyah rupit. Sebagai seorang yang dianggap mampu, professional atau ahli, untuk meningkatkan kualitas masrasah khususnya di MA Al-Mathiriyah rupit ini, sehingga etos kerja guru semakin meningkat. Dalam hal ini kepala madrasah MA Al-Mathiriyah rupit menjelaskan bahwa :

"Walaupun saya MA Al-Mathiriyah rupit, namun saya belum begitu ahli dalam membimbing dan mengarahkan guru namun saya tetap berusaha melakukan pendekatan-pendekatan personal/ perseorangan,dengan melalui analisis work dengan cara membentuk timework. Timework yang. sudah dibentuk dan dijalankan serta sudah di SK kan yaitu dengan membentuk kelompok yaitu : kelompok mata pelajaran umum, kelompok mata pelajaran jurusan, kelompok mata pelajaran bahasa, serta membuat penugasan khusus yaitu SP guru yaitu PNS atau non PNS”, 
Seorang pemimpin yang frofesional dalam bidangnya, harus mampu me trik-trik atau memiimpin bawahannya dalam berbagai kondisi walaupun dengan keterbatasan yang dihadapida yang dimilikinya, dan juga ahli dalam melakukan dan mengatasi berbagai persolan-persoalan atau permasalahan-permasalahan yang ada disekitar lingkungannya serta bagaimana strategi dalam menentukan dan meningkatkan etos kerja guru dan kinerja guru di madrasah terutama di MA AlMathiriyah Rupit.

Seperti apa yang disampaikan juga oleh pak alxsander, pak aguscik, dan ibu marfiroh, mengenai keprofesionalitas atau sesorang dalam memimpin suatu lembaga terutama lembaga pendidikan di MA Al-Mathiriyah rupit.

"Kepala MA Al-Mathiriyah Rupit, telah melakukan pendekatan-pendekatan personal dalam mendengar keluhan-keluhan yang dialami oleh bawahannya, salah satunya adalah bagaimana cara mengatasi kesulitan dalam menjalani proses pembelajaran di MA Al-Mathiriyah Rupit,serta memberikan tugas kepada kami untuk membuat kelompok kerja bidang studi yang berbagi dalam berbagai kelompok yaitu kelompok bidang studi jurusan, serta membuat kelompok khusus yaitu pembinaan-pembinaan dan pengawasan terhadap pegawai dalam meningkatkan etos kerja dan kinerja guru serta karyawan/staf yang nantinya disampaikan setiap persemester dan akhir tahun secara bersama-sama semua kelompok pada kegiatan tersebut sedah dibuatkan SK nya"

Sebagai seorang pemimpin yang frofesional dan ahli dalam bidangnya, tentu dia harus lebih berhati-hati dalam dan memberikan pengalaman-pengalamannya kepada bawahannya, dan selalu mlengadakan pendekatan-pendekatan yang frofesional vbaik secara personal maupun dengan cara lain apakah itu secara terbuka atau tertutup sehingga bawahannya merasa akan selalu diperhatikan dalam menjalankan tugansya.

Kepala madrasah tidak hanya sekedar pemimpin yang hanya memerintahkan dan menyuruh bawahannya bekerja tanpa ada pengawasan yang rutin dan mengevaluasi hasil kerja bawahannya. Seseorang pemimpin dalam mengawasi dan memperhatikan bawahannya dalam bekerja dengan baik dan sukses sesuai dengan tujuan yang dicapai, maka hendaknya diperhatikan pula jerih payahnya bagaimana member ganjaran atau pujian yang menyenangkan bagi bawahannya, walaupun hanya sekedarnya saja. Dan sebaliknya apabila bawahannya bekerja dalam melaksanakan tlugasnya terbengkalai dan ambaradul atau tidak berbuah hasil, maka perlu diberi teguran dan serta diberikan hukuman yang sesuai dengan tingkatan keberhasilannya. Sehingga cara bapak selalu memotivasikan bawahannya untuk meningkatkan etos kerja guru dan kinerja guru.

Dalam rangka upaya meningkatkan etos kerja guru dan kinerja guru, maka seorang pemimpin dalam hal ini kepala Madrasah, perlu memberikan sanjungan/pujian kepada bawahannya apabila bahwahannya dapat melaksanakan 
tuasnya dengan baik. Dan sebaliknya apabila bahwahannya membuat kesalahan dalam melaksanakan tugas, maka perlu diberi hukuman dimana hukuman itu jangan sampai menyinggung perasaan, apalagi meyakiti perasaannya, maka hendaklah melakukan dengan bijak dalam mengambil keputusan.

\section{Pembinaan Manajemen Manusia dalam Meningkatkan Kinerja Guru dalam Mengelola Madrasah}

Berbicara mengenai menenejem etos kinerja guru dalam meningkatkan sumber daya manusia yang baik yaitu perlu semangat para dewan guru dalam melakukan suatu pekerjaan yang mendatangkan hasil dan dengan hasil kerja guru maka terciplah sumber daya yang baik dan bermutu. Dalam kehidupan seharihari,seorang agaknya akan sulit melakukan pekerjaan atau tugasnya dengan baik dan tekun serta memiliki komitmen terhadap criteria tersendiri. jika pekerjaan itu kurang bermakna baginya dan tidak bersangkutan dengan tujuan hidupnya. Cara kerja yang memandang pekerjaannya sebagai kegiatan untuk mencari nafkah semata-mata atau hanya untuk memperoleh upah atau gaji dang sadang pangan demi fisik jangka pendek, agaknya akan berbeda dengan cara kerja seorang memandang tugasnya atau pekerjaanya sebagai Calling dan amanah yang hendak di pertanggung jawabkan dihadapan tuhan. Munculnya sikap malas, santai dan tidak disiplin waktu bekerja dapat bersumber dari pandangan terhadap pekerjaan dan tujuan hidup.

Berikut ini wawancara penulis dengan kepala MA Al-Mathiriyah Rupit tentang salah satu kinerja guru yang tampak selama proses pembelajaran di madrasah ini.

"Selama saya kepala madraah MA Al-Mathiriyah Rupit kurang lebih tiga tahun, saya sangat berterima kasihb sekalai semua kepada dewan guru dan staf lainnya yang telah bekerja keras membantu saya dalam mengejar ketercapaian/kelulusan 100\% bagi anak didik kami dalam mengikuti ujian nasional (UN) atau Ujian Akhir Madraah Berstandar Nasional (UANMBN) dan begitu pula telah membimbing siswa/i dalam mengikuti berbagai perlombaan-perlombaan, dianttaranya lomba Paskibraka,,pramuka, dan lomba seni budaya islami, baik tingkat kabupaten taupun provinsi baik ya $h$ diselenggartakan olek kemanag kabupaten/provinsi.

Semangat kerja bagi dewan guru, apakah ia professional atau kah tidak, kalau dia sanggup dan focus dalam menjalankan tugas-tugasnya dengan baiik, ikhlas dan penuh kesadaran seta bertanggung jawab, maka kinerja guru akan datang dengan sendirinya, dan akan menguntungkan bagi dirinya atau instansinya yang dimana ia bertugas. Suatu pekerjaan yang dilakukan dengan rasa kesadaran yang tinggi dan ikhlas berkrja dan bekerja dengan seikhlas-iklasnya, asalkan mampu menjalankannya dengan tanggung jawab, maka pekerjaan itu dapat 
dilaksanakan sesuai dengan yang diharapkan setiap orang, walaupun bukan bidangnya sekalipun.

Menurut saya apa yang dilakukan oleh kepala sekolah, sudah benar sesuai dengan kebijakannya,seperti dengan memenuhi jam mengajar para dewan guru yaitu dengan mata pelajaran yang serumpuh, karena ini menyangkut dengan peraturan undang-undang serta tuntunan kurikulum. Setelah menyimak atas pembinaan etos kerja guru ketercapaian kinerja guru MA Al-Mathiriyah dalam meningkat menejemen sumber daya manusia. Maka hasil dari hasil wawancaran, menyimpulkan bahwa etos kerja guru di madrasah idak hanya mengajar atau bertatap muka di kelas, namun di tntut juga kegiatan luar jam mengajar yaitu berupa pelaksanaan kegiatan pembinaan dan estrakurikuler.

Kinerja guru memang yang baik adalah bagaimana seorang guru itu juga mampu membuat dan melengkapi perangkat pembelajaran yang standard an sesuai dengan petunjuk dak teknis. Karena dalam melaksanakan tugasnya guru harus punya acuan dan pedoman dalam mengajar dikelas. Maka siswa yang diajarkan menjadi anak didik yang menjadi kebanggaan madrasah itu sendiri sehingga dengan adanya tersebut maka akan tercipta seumber daya manusia yang baik dan cerdas.

Menurut hemat penulis, setelah beberapa yang penulis wawancara kepada kepala sekolah MA-Al-Mathiriyah ada beberapa yang dapat diambil kesimpulan diantaranya adalah; Perlu adanya pembinaan terhadap kerja para guru sehingga akan menghasilkan guru yang disiplin dan siswa yang memuaskan; Menanamkan semngat guru atau kerja guru uang ikhlas dan penu kesadaran sesuai dengan tofuksi yang ada pada guru salah satunya kelengkapan perangkat pembelajaran; Melibatkan semua dewan guru dan staf/karyawan dalam memecahkan suatu masalah dengan bentuk kerja kelompok dan evaluasi secara bersama-sama; Dalam rangka meningkat sumber daya manusia dan kinerja guru, perlu adanya usaha peningkatan ataupun pembinaan kesejahteraan para guru, dan syaf/karyawan; Menciptakan suasana kerja yang nyaman dan bersahabat, dengan cara mengadakan pendekatan-pendekatan personal dalam melaksanakan suatu pekerjaan; Perlu adanya pembinaan- pembinaan bertahap terhadap kerja para guru. Sehingga\akan menghasilkan keinerja guru yang memuaskan; Menanamkan semngat bekerja yang ikhlas yan penuh kesadaran sesuai dengan tofoksi yang ada pada guru salah satunya kelengkapan persngkstsn pembelajaran.

\section{Factor dan Pendukung dalam Meningkatkan Sumber Daya Manusia}

Factor internal yang sangat pengaruh dalam menjalankan tugasnya adalah buku pegangan guru dan buku siswa yang sesuai dengan kurikulum yang berlaku. Namun disatu sisi ada salah satu guru yang mecari buku lewat internet mengenai factor eksternal adanya perlunya dekungan atau respon serta komunikasi yang lancer antara madrasah dengan komite serta masyarakat yang ada dilungkungan 
madrasah dalam hal ini ada beberapa upaya Kepala Madrasah MA Al-Mathiriyah dalam melaksanakn tugasnya sebagai seorang pemimpin diantaranya :

Upaya kepala sekolah sangat penting dalam melaksanakan, merencanakan kedepan semua program madrasah yang disesuaikan dengan visi dan misi madrasah itu sendir, dalam menghadapi persaingan antar pendidikan yang disesuaikan dengan perkembangan pendidikan yang begitu pesat pada saat sekarang ini dan juga kepala madraah dituntut keahliannya dalam mengelola madrasah walaupun masih ada kekurangan-kekurangan yang dihadapi

Ketercapaian tujuan pendidikan sangatlah bergantung padal kecakapan dan kebijaksanaan kepala madrasah sebagai seorang pemimpin pendidikan. Hal ini karena kepala madrasah merupakaln seorang pejabat yang bertugas mengatur semua sumber organisasi dan bekerja sama dengan guru-guru, staf/karyawan dalam menentukan nasib siswa/I untuk mencapai tujuan pendidikaln yang baik. Kepala MA Al-Mathiriyah merupakan kunci kesuksesan madrasah dalam mengadakan inovasi, kreativitas, kedisiplinan proses pelaksanaan kegiatan madrasah sehingga akan meningkatkan dan memperbaiki semua program dan proses pembelajaran semuanya Itergantung bagaiaman upaya seorang kepala dalam bekerja dan meningkatkan etos kerja guru yang nantinya akan Nampak kenerja para gurunya

Dalam meningkatkan kerja guru yang berkualitas, usaha-usaha yang dilakukan kepala madrasah tidak hanya diserahkan kepada individu saja, tetapi melainkan juga harus melibatkan semual lkomponen madrah. Data-data yang telah berhasil dikumpulkan dianalisa,ditemukan sudut persoalannya,dan dimungkinkan didapatkan alternatif pemecahannya data-data yang telah terkumpul memberikan kesimpulan atas data atau impormasi yang diperoleh dari orang-orang yag ditanya tentang kepala MA Al-Mathiriyah dalam meningkatkan etos kerja guru, dinilai cukup baik, dari impormasi ini penulis dapat menyimpulkan bahwa upaya kepala sekolah MA Al-Mathiriyah dalam meningkat etos kerja guru memberikan hasil yang cukup memuaskan karena masing-masing pihak terkait dalam pelaksanaannya tidak lagi bersifat persial dan mengukur kinerja keberhasilan berdasarkan perspektif masing-masing.

Factor dan pendukung dalam meningkatkan Dalam Meningkatkan Etos sumber daya manusia di Madrasah Al-Mathiriyah Kecamatan Rupit Kabupaten Musi Rawas Utara. Dalam meningkatkan etos kerja guru di MA Al-Mathiriyah salah satunya sikap kejujuran, kesadaran, dan keikhlasan, guru dalam melaksanakan tugas. Dari hasil pengamatan wawancara dengan guru dapat dilihat dari prilaku dan sikap dalam keseharian yang dicerminkan dalam diri seorang guru adalah kedisiplinan, kepuasan serta kenyamanan. Kepala MA Al-Mathiriyah mengupayakan demikian rupa tentang bagaimana memanfaatkan segala sumber daya yang ada meskipun kondisi madrasah masih sangat sederhana, baik kondisi gedung, ruang belajar, serta sarana prasarana lainnya dalam mempelancar proses pembelajaran di madrasah. Pembinaan-pembinaan yang dilakukan oleh kepala 
MA Al-Mathiriyah mendapat dukungan positif dari seluruh gur dan staf/karyawan.

Dari beberapa guru mengemukankan bahwa kegiatan belajar mengajar senantiasa tetap dilaksanakan dengan penuh kesadaran dan keikhlasan serta tanggung jawab sebagai guru. Dengan adaya sikap kesadaran, keikhlasan, dan kejujuran merupakan indentitas awal seseorang dapat dipercaya, sikap ini mempu mengembangkan pribadi guru didepan siswa. Diantara dukungan itu datang dari salah seorang guru yang diikut sertakan dalam beberapa pelatihan, seminar, worshop, melanjutkan study pendidikan kejenjang lebih tinggi baik honor maupun yang PNS.

Faktor penghambat salah satunya ialah keterbatasan sarana prasarana yang menunjang bagi suasana kegiatan yang nyaman. Mengenai ruang belajar sudah cukup memadai, namun ada beberapa yang selalu menganjal dalam pelaksanaan kegiatan pembelajaran yakni, buku-buku terbatas, dimana para gurunya untuk mendapatkan buku-buku tersebut, didapat dari kopian melalui internet beberapa peralatan dan perlengkapan yang ada kurang sesuai dengan kebutuhan dan karakteristik madrasah lain yang sudah maju. Pembelajaran merupakan intraksi siswa dengan lingkungan yang dipengaruhi factor internal maupun factor eksternal. Keterbatasan sarana yang dapat dilakukan dengan mengkondisikan lingkungannya agar menunjang terjadinya perubahan pada siswa. Kemudian suasana mengajar yang kurang mengairahkan. Ada tiga langkah strategi yang perlu diapresiasi bagi perubahan prilaku siswa dalam konteks pembelajaran di madrasah. 1) appersepsi, yaitu menghubungkan materi pembelajaran dengan pengalaman siswa atau dengan kompetensi yang telah dikuasi. Appersepsi, dapat dilakukan dalam bentuk pre-test yang sebaik-baiknya sesuai dengan kebutuhan 2) penyampaian materi dan latihan (exercise) seni pembelajaran dapat dilihat dari segi proses dan hasil. Dari segi proses, pmbelajaran, baik fisik, mental maupun social. Mereka mampu menunjukkan kegiatan belajar dikatalkan efektif dan berhasil apabila ada perubahan pengetahuan, sikap dan prilaku positif pada siswa. 3) evaluasi, yaitu adanya pelaksanaan pembelajaran yang diakhiri dengan evaluasi atau pos-test. Tujuan utama evaluasi ini adalah untuk mengetahui tingkat keberhasilan siswa dalam proses pembelajaran di kelas. Dan juga menjadi tolak ukur bagi guru dalam penyampaian dan keterbatasan siswa dalam menerima materi selama proses pembelajaran di madrasah.

\section{SIMPULAN}

Kepala MA Al-Mathiriyah dalam mengelola atau memimpin bawahannya hendaknya dapat melaksanakan, merencanakan, dan professional, serta ahli bidangnya, serta mampu member penghargaan dan pujian yang setinggitingginya, serta pujian atau sanjungan terhadap hasil kerja bawahannya. Namun tak terlepas dari itu, apabila bawahannya atau palra guru yang melanggar kode etiknya dalam melaksanakan tugalsnya beralih hukuman yang tidak sesuai 
dengan kode etik guru. Dan tak lepas kalah pentingnya adalah mendapingi dan mengawasi, membina, kerja para guru dengan cara melakukan pendekatanpendekatan personal, sehingga para guru tersebut tersa termonivasi dalam melaksanakan tugas dan kewajibannya.Kepala sekolah sangat berperan sekali dalam meningkatkan dan motivasi para guru, staf /karyawan, dalam meningkatkan prestasi siswa/I nya, yang sudah berjalan secara efektif dan kondisonal. Contoh pada tahun 2003-2005 siswanya mencapai hasil yang memuaskan yaitu Rata-rata $100 \%$ ini menunjukkann balhwa salah satu dari etos kerja guru dalam menghasilkan kinerja guru. Dalam memberikan peluang dan kesempatan kepada para gurunya untuk mengikuti pendidikan dan pelatihan yang diadakan oleh pemerintah dan memberikan kesempatan bagi para guru yang untuk melanjutkan jenjang studi yang lebih tinggi.Seorang kepala sekolah yang cerdas, kreatif dan tanggap, dia harus mampu mengatasi dan mencari solusi dalam masalah yang dihadapi yaitu ;1) faktor personal atau individual yang meliputi pengetahuan, pengetahuan, motivasi, dan komitmen yang tinggi, 2) menciptakan suasana kerja yang menggairahkan dan penuh kekeluargaan, 3) volum atau upah gaji bukanlah factor utama dalam meningkatkan etos kerja guru dan kinerja guru, tetapi adalah kanyamanan kerja dan ketenangan hidup

\section{DAFTAR PUSTAKA}

Dharma, S. (2005). Manejemen Kinerja. Jakarta: Penerbit: Pustaka Pelajar

Sahertian, F. (1990). Supervisi Pendidikan Dalam Rangka Program Inservise Education. Jakarta: Renika Cipta

Soecipto, S., \& Kosasi, R. (2007). Profesi Keguruan. Jakarta: Rineka Cipta 